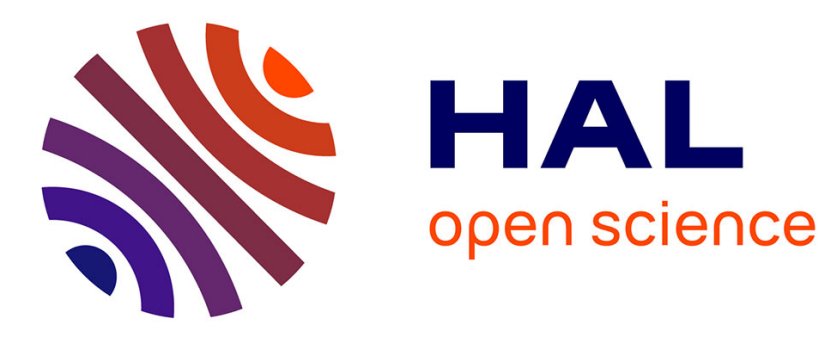

\title{
Social cost of carbon: global duty
}

Céline Guivarch, Aurélie Méjean, Antonin Pottier, Marc Fleurbaey

\section{To cite this version:}

Céline Guivarch, Aurélie Méjean, Antonin Pottier, Marc Fleurbaey. Social cost of carbon: global duty. Science, 2016, 351 (6278), pp.1160 61. 10.1126/science.351.6278.1160-b . halshs-01290282

\section{HAL Id: halshs-01290282 https://shs.hal.science/halshs-01290282}

Submitted on 17 Apr 2018

HAL is a multi-disciplinary open access archive for the deposit and dissemination of scientific research documents, whether they are published or not. The documents may come from teaching and research institutions in France or abroad, or from public or private research centers.
L'archive ouverte pluridisciplinaire HAL, est destinée au dépôt et à la diffusion de documents scientifiques de niveau recherche, publiés ou non, émanant des établissements d'enseignement et de recherche français ou étrangers, des laboratoires publics ou privés. 


\section{Social cost of carbon: global duty}

This text is a post-print from: Guivarch, C., Mejean, A., Pottier, A., Fleurbaey, M., 2016. "Social cost of carbon: global duty", Science 351 (6278): 116061.

In their Letter "Social cost of carbon: Domestic duty" (5 February, p. 569), A. Fraas et al. argue that regulations to limit greenhouse gas emissions in the United States should be evaluated in the light of the domestic benefits they provide instead of global benefits as recommended by the Interagency Group on the Social Cost of Carbon (2010) (1). This idea, which has already been put into practice by some (2), may seem reasonable. However, climate change is a special case. No matter where a ton of carbon is emitted, it has the same impact on the atmosphere, and it ultimately leads to the same damages from climate change. As a consequence, if the United States avoids emissions, it will also benefit other countries in the same way as reducing emissions in other countries will benefit the US.. If every country adhered to Fraas et al.'s proposal to focus only on its domestic benefits, all countries would end up worse-off. This was demonstrated at the beginning of climate change economics (3).

This situation is similar to the prisoner's dilemma (4), in which prisoners in separate rooms are given the opportunity to betray each other in exchange for a reduced sentence. Betrayal offers a greater reward than cooperation, unless both prisoners cooperate. Given the rules of the scenario, all rational self-interested prisoners would betray one another, leading to an outcome worse than if they had cooperated. In the case of climate change, we are in a better position than the prisoners in one way: We can talk to each other and decide to cooperate. In fact, we did so already. In Paris, last December, 195 countries decided to hold "the increase in the global average temperature to well below $2^{\circ} \mathrm{C}$ above preindustrial levels and to pursue efforts to limit the temperature increase to $1.5^{\circ} \mathrm{C}$ above pre-industrial levels, recognizing that this would significantly reduce the risks and impacts of climate change." (5). Meeting this goal will not be possible if every country focuses only on its domestic benefits. The Interagency Group on the Social Cost of Carbon is right to recommend using global benefits to evaluate mitigation projects and regulations, and every country that is not doing so should follow the lead.

Céline Guivarch, ${ }^{1}$ Aurélie Méjean, ${ }^{2}$ Antonin Pottier, ${ }^{3}$ Marc Fleurbaey $_{3}^{4}$ ${ }^{1}$ Ecole des Ponts ParisTech, CIRED, Nogent-sur-Marne, 94130, France. ${ }^{2}$ CNRS, CIRED, Nogent-sur-Marne, 94130, France. MINES ParisTech, PSL Research University, CERNA - Centre for industrial economics, i3, CNRS UMR 9217, Paris, 75006, France. ${ }^{4}$ Woodrow Wilson School of Public and International Affairs-University Center for Human Values, Princeton University, Princeton, NJ 08544, USA.

*Corresponding author. E-mail: guivarch@centre-cired.fr

\section{References}

1. Interagency Working Group on Social Cost of Carbon, Technical Support Document: Social Cost of Carbon for Regulatory Impact Analysis Under Executive Order 12866 (White House, Washington, DC, 2013); http://1.usa.gov/18ftAsH

2. P. Watkiss, C. Hope, Wiley Interdisciplinary Reviews: Climate Change 2, 886 (2011).

3. W. D. Nordhaus, Z. Yang, Am. Econ. Rev. 86, 741 (1996).

4. A.W. Tucker, A two-person dilemma, mimeo, Stanford University (1950), reproduced in E. Rasmusen, Ed., Readings in games and information (Wiley-Blackwell, Oxford, 2001).

5. Paris Agreement, as contained in the report of the Conference of the Parties on its twenty-first session, FCCC/CP/2015/10/Add.1; http://unfecc.int/meetings/paris_nov_2015/items/9445.php 